\title{
Performance, egg quality, blood profile, immune function, and antioxidant enzyme activities in laying hens fed diets with thyme powder
}

KEY WORDS: antioxidant enzymes, lipid profile, immune system, thyme, performance, layers

Received: 30 March 2015

Revised: 25 April 2015

Accepted: 15 June 2015
${ }^{1}$ Corresponding author:

e-mail:dr.mahmoud.alagwany@gmail.com

\begin{abstract}
This study evaluated the effect of thyme (Thymus vulgaris L.) on productive performance, egg quality, blood profile, immune function and antioxidant enzyme activity in laying hens. A total of 96 thirty-six-week-old laying hens were assigned to a basal control diet or a diet supplemented with 3,6 , or $9 \mathrm{~g} \cdot \mathrm{kg}^{-1}$ of thyme fed from 36 to 52 weeks of age. Hens were divided into four equal groups replicated six times with four hens per replicate. No significant differences were observed among the dietary treatments in body weight change, feed consumption, or feed conversion ratio. Supplementation of thyme up to $6 \mathrm{~g} \cdot \mathrm{kg}^{-1}$ in the diet led to an increase in egg weight compared with the basal diet. Egg number was not $(P>0.05)$ influenced by thyme supplementation, except from 36 to 40 weeks of age. Birds fed diets with 3 or $6 \mathrm{~g} \cdot \mathrm{kg}^{-1}$ of thyme had greater $(P<0.05)$ egg mass than those fed the unsupplemented diet or that with $9 \mathrm{~g} \cdot \mathrm{kg}^{-1}$ of thyme. Dietary supplementation with thyme exhibited a significantly positive effect on parameters related to immunity and lipid profile. Serum superoxide dismutase activity and reduced glutathione concentration were significantly increased in groups fed diets with thyme $(P=0.010$ and $P<0.001$, respectively). The malondialdehyde concentration was decreased $(P=0.048)$ in experimental groups in comparison with the control. In conclusion, thyme supplemented up to $9 \mathrm{~g} \cdot \mathrm{kg}^{-1}$ diet can be used as an effective feed additive to improve productive performance, blood profile and antioxidant enzyme activities in laying hens.
\end{abstract}

\section{Introduction}

Phytogenic feed additives (PFA) and supplements are attaining importance nowadays in animal and poultry production, as well as in health care systems, because of their wide spectrum of beneficial effects, such as promoting growth and production, immune enhancement and health protection (Alagawany et al., 2015a,b). Some studies have described different biological and protective effects of thyme, including antioxidant, antibacterial, anti-inflammatory, immunomodulatory and health-promoting activities (Dhama et al., 2014, 2015).

Thyme (Thymus vulgaris L.) and its effective components enhance the digestive activity of enzymes like protease, amylase and lipase, which results in improved digestibility of nutrients (Abd El-Wareth et al., 2012). Also, these plants of the Labiatae family are used as disinfectants and to improve digestion and absorption. The last two effects 
are attributed to increase in intestine length and in the depth and width of the villi, thus creating better conditions for nutrient absorption (Alcicek et al., 2003). Nonetheless, there is limited knowledge about the second cycle of hens, as well as about the effects of thyme alone, in contrast to data on the essential oils of this herb. Phytogenic feed additives, including thyme, exert their antioxidant mechanism via eradication of free radicals, constitution of chelates with metal ions, and prevention or reduction of oxygen formation (Rice-Evans et al., 1995; Khan et al., 2012).

Even today, there is considerable potential to support gut health and positively affect performance using PFA in livestock species (Ashour et al., 2014). Nonetheless, usage of herbal plants or their effective compounds in laying hen diets has been investigated only in a limited number of in vivo trials (Bozkurt et al., 2014). Therefore, the main objectives of the present study were to evaluate the effects of different levels of thyme on improving productive performance, egg quality criteria, and blood metabolites, as well as the oxidative status parameters of laying hens.

\section{Material and methods}

This study was conducted at the Poultry Research Farm, Department of Poultry, Faculty of Agriculture, Zagazig University (Egypt). All of the experimental procedures were carried out according to the Local Experimental Animal Care Committee, and approved by the institutional ethics committee. Birds were cared for using husbandry guidelines derived from Zagazig University standard operating procedures.

\section{Birds, experimental design, and diets}

A total of 96 Hi-sex Brown laying hens were used in the experiment having a completely randomized design, with six replications of 4 hens each; four birds were housed per wire cage $(50 \times 50 \times 45$ $\mathrm{cm})$. The cages were equipped with a nipple drinker and trough feeders. The bird house was provided with programmable lighting and adequate ventilation. The lighting programme at the start of the trial was $14 \mathrm{~h}$ of light and was increased by $15 \mathrm{~min}$ each week to $17 \mathrm{~h}$ of light. The diets and water were provided ad libitum throughout the experiment. Each experimental diet was formulated to meet the nutrient recommendations in the Hi-sex Brown management guide, which meets or exceeds the NRC (1994) recommendations. Experimental diets were iso-caloric $\left(2800 \mathrm{kcal}\right.$ of $\left.\mathrm{ME} \cdot \mathrm{kg}^{-1}\right)$ and isonitrogenous (18\% crude protein). The duration of the experiment was 16 weeks (between 36 and 52 weeks
Table 1. Composition and nutrient content of the basal diet fed to laying hens

\begin{tabular}{lr}
\hline Indices & Control diet \\
\hline Ingredient, $\%$ & \\
yellow maize & 56.71 \\
soyabean meal (44\% CP) & 28.62 \\
soyabean oil & 3.13 \\
limestone & 9.33 \\
di-calcium phosphate & 1.45 \\
salt & 0.30 \\
vitamin-mineral premix ${ }^{1}$ & 0.30 \\
dl-methionine & 0.16 \\
Calculated composition ${ }^{2}$ & \\
ME, kcal · kg ${ }^{-1}$ & 2800 \\
crude protein, $\%$ & 17.51 \\
Ca, $\%$ & 4.00 \\
non-phytate P, $\%$ & 0.38 \\
lysine, $\%$ & 0.92 \\
TSAA, $\%$ & 0.73 \\
threonine, $\%$ & 0.65 \\
valine, $\%$ & 0.81 \\
tryptophan, $\%$ & 0.24 \\
crude fibre, $\%$ & 3.25 \\
crude fat, $\%$ & 2.38 \\
linoleic acid, \% & 2.92 \\
\hline
\end{tabular}

${ }^{1}$ vitamin-mineral premix: $1 \mathrm{~kg}$ of premix consists of: IU: vit. A 8000; ICU: vit. $D_{3} 1300$; $m g$ : vit. $E 5$, vit. $K 2$, vit. $B_{1} 0.7$, vit. $B_{2} 3$, vit. $B_{6} 1.5$, vit. $B_{12}, 7$, biotin 0.1 , folic acid $1, \operatorname{Mn~} 60, \mathrm{Zn} 50, \mathrm{Cu} 6, \mathrm{I} 1$, Se 0.5, Co 1; g: pantothenic acid 6, niacin 20; ${ }^{2}$ calculated according to NRC (1994); TSAA - total sulphur amino acids

of age). The dietary treatments were as follows: 1. control (basal diet with no additive), 2. basal diet with $3 \mathrm{~g} \cdot \mathrm{kg}^{-1}$ of thyme powder, 3 . basal diet with $6 \mathrm{~g} \cdot \mathrm{kg}^{-1}$ of thyme powder, and 4 . basal diet with $9 \mathrm{~g} \cdot \mathrm{kg}^{-1}$ of thyme powder. The diets were fed in mash form. The formulation and composition of the basal diet are shown in Table 1. Thyme powder is a commercial product and was purchased from Free Trade Egypt Company, Behira (Egypt).

\section{Data collection and egg parameters}

The laying hens were weight at the start and end of the experiment. Body weight changes (BWC) were calculated as the difference between the initial and final body weights. Feed consumption (FC) was recorded and calculated as the decrease, in grams, of feed over 7 days, divided by the number of bird days, adjusted for mortalities. The feed conversion ratio (FCR) (grams feed per gram of egg) was calculated as the egg mass (EM) divided by the amount of consumed feed. Eggs were collected daily and the egg number was calculated on a hen-day basis. Egg weight (EW) and egg number were recorded daily to calculate the egg mass (egg number $\times$ egg weight). 


\section{Egg quality criteria}

Eggs were examined for interior and exterior quality. Egg components were measured monthly using three eggs from each treatment replicate. Eggs were weighed, their egg length and width were determined before breaking. The egg was carefully broken on a glass plate $(35 \times 25 \mathrm{~cm})$. The yolk was separated from the albumen. Egg shells were cleaned of any adhering albumen. Albumen weight was calculated by subtracting the weight of the yolk and shell from the whole egg weight. The egg shape index was computed as the ratio of egg width to length (Awosanya et al., 1998). The yolk index was calculated according to Funk et al. (1958), as the average yolk height divided by yolk diameter $(\mathrm{mm})$ following removal of the yolk from the albumen. Yolk height was measured by means of a tripod micrometre reading to the nearest $0.01 \mathrm{~mm}$, while yolk diameter was measured by a vernier caliper to the nearest $0.05 \mathrm{~mm}$. Haugh units were calculated as:

$$
\text { Haugh units }=100 \log \text { [albumen height }(\mathrm{mm})+
$$

$$
\left.+7.57-1.7 \text { egg weight } t^{0.37}(\mathrm{~g})\right]
$$

according to the formula proposed by Card and Nesheim (1972).

The eggs were examined for shell quality on the basis of shell thickness (with shell membrane), which was measured by a micrometre. Shell thickness is given as the mean value of measurements at three locations on the eggs (air cell, equator and sharp end).

\section{Blood sampling and laboratory analyses}

Blood samples were randomly collected from six birds per treatment from the wing vein into sterilized tubes closed with rubber stoppers. The samples were left to coagulate and then centrifuged at $3500 \mathrm{rpm}$ for $15 \mathrm{~min}$ to obtain serum; the serum samples were kept in Eppendorf tubes at $-20^{\circ} \mathrm{C}$ until analysis. The following serum biochemical parameters levels were determined spectrophotometrically using commercial diagnostic kits provided from Biodiagnostic Co. (Giza, Egypt): total protein $\left(\mathrm{g} \cdot \mathrm{dl}^{-1}\right)$, albumin $\left(\mathrm{g} \cdot \mathrm{dl}^{-1}\right)$, urea $\left(\mathrm{g} \cdot \mathrm{dl}^{-1}\right)$, triglycerides $\left(\mathrm{mg} \cdot \mathrm{dl}^{-1}\right)$, total cholesterol $\left(\mathrm{mg} \cdot \mathrm{dl}^{-1}\right)$, high-density lipoprotein (HDL) cholesterol (mg · $\mathrm{dl}^{-1}$ ), low-density lipoprotein (LDL) cholesterol $\left(\mathrm{mg} \cdot \mathrm{dl}^{-1}\right)$ and immunoglobulins $\mathrm{G}(\mathrm{IgG}), \mathrm{M}(\mathrm{IgM})$ and A (IgA) (Akiba et al., 1982).

For antioxidant assays, serum samples were used for measurement of superoxide dismutase (SOD) activity, as well as reduced glutathione
(GSH) and malondialdehyde (MDA) concentrations by spectrophotometric methods using a spectrophotometer (Hitachi, Japan). SOD activity was determined by the xanthine oxidase method, which monitors the inhibition of reduction of nitro blue tetrazolium by the sample (Winterbourn et al., 1975). The GSH concentration was assayed by the method of Beutler et al. (1963). The MDA level was determined with 2-thiobarbituric acid, monitoring the change of absorbance at $532 \mathrm{~nm}$ with a spectrophotometer (Jensen et al., 1997).

\section{Statistical analysis}

Data were subjected to the ANOVA procedure for a completely randomized design using the GLM procedures of SPSS (version 17.0, 2008). The differences among means were determined using the post-hoc Newman-Keuls test. Statements of statistical significance are based on $P<0.05$ unless otherwise stated.

\section{Results and discussion}

\section{Hen productive performance}

The effect of dietary thyme supplementation on the performance of laying hens during the experimental period is shown in Table 2. There were no differences in BWC, feed consumption or FCR among treatments during the different phases. However, feed consumption was increased and FCR was decreased after thyme supplementation compared with the basal diet $(P<0.05)$. Diets with added thyme were consumed without any palatability problems. The results of the current study are in line with the findings of Mohebbifar and Torki (2010), who found that PFA supplementation to a basal diet had no effect on feed intake or feed conversion ratio compared with the unsupplemented diet. Similarly, Amad et al. (2011) noted that PFA containing essential oil from thyme enhanced the feed conversion ratio, while body weight change was not significantly affected. Medicinal plant supplementation to poultry diets improved feed efficiency in the study by Hong et al. (2012), whereas their effect on feed consumption and body weight gain were not consistent with previous findings. In an earlier study, an improvement in body weight and gain was observed when birds were fed diets with thyme (Tiihonen et al., 2010).

Egg weight was significantly influenced by the treatments $(P<0.05$; Table 2$)$. Its highest values were observed in birds fed 3 or $6 \mathrm{~g} \cdot \mathrm{kg}^{-1}$ of thyme 
Table 2. Effects of dietary thyme supplement on productive performance traits of laying hens at different phases

\begin{tabular}{|c|c|c|c|c|c|c|}
\hline \multirow{2}{*}{ Performance } & \multirow{2}{*}{ Control } & \multicolumn{4}{|c|}{ Thyme, $\mathrm{g} \cdot \mathrm{kg}^{-1}$ of control diet $\mathrm{SEM}{ }^{1}$} & \multirow{2}{*}{$P^{2}$} \\
\hline & & 3 & 6 & 9 & & \\
\hline \multicolumn{7}{|c|}{ Body weight gain, $\mathrm{g}$} \\
\hline initial & 1604 & 1652 & 1664 & 1622 & 17.51 & 0.310 \\
\hline final & 1822 & 1853 & 1869 & 1837 & 20.39 & 0.114 \\
\hline change & 218 & 201 & 205 & 215 & 27.40 & 0.072 \\
\hline \multicolumn{7}{|c|}{ Daily feed consumption, $\mathrm{g}$} \\
\hline week 36-40 & 82.20 & 93.11 & 95.22 & 81.52 & 2.62 & 0.129 \\
\hline $40-44$ & 90.97 & 97.23 & 100.93 & 91.88 & 1.91 & 0.219 \\
\hline $44-48$ & 86.59 & 95.17 & 98.07 & 86.70 & 2.21 & 0.148 \\
\hline $48-52$ & 88.78 & 96.20 & 99.50 & 89.29 & 2.04 & 0.173 \\
\hline $\begin{array}{l}\text { overall } \\
36-52\end{array}$ & 87.13 & 95.43 & 98.43 & 87.35 & 2.16 & 0.153 \\
\hline \multicolumn{7}{|c|}{ Feed conversion ratio, $g$ feed per g egg } \\
\hline week $36-40$ & 2.07 & 1.81 & 1.98 & 1.75 & 0.07 & 0.411 \\
\hline $40-44$ & 1.99 & 1.73 & 1.92 & 2.09 & 0.09 & 0.637 \\
\hline $44-48$ & 1.91 & 1.83 & 1.88 & 1.85 & 0.07 & 0.981 \\
\hline $48-52$ & 1.95 & 1.78 & 1.90 & 1.97 & 0.08 & 0.866 \\
\hline $\begin{array}{l}\text { overall } \\
36-52\end{array}$ & 1.98 & 1.79 & 1.92 & 1.92 & 0.07 & 0.850 \\
\hline
\end{tabular}

Egg weight, $g$

week $36-40$

40-44

$61.31^{\mathrm{b}} \quad 64.50^{\mathrm{ab}}$

$66.21^{\mathrm{a}}$

$\begin{array}{lll}62.41^{\mathrm{b}} & 0.67 & 0.034\end{array}$

$40-48$

$63.23^{\mathrm{ab}} 64.92^{\mathrm{b}}$

$65.28^{\mathrm{a}}$

$\begin{array}{lll}61.27^{\mathrm{b}} & 0.60 & 0.045\end{array}$

$48-52$

$64.49^{\mathrm{ab}} \quad 66.21^{\mathrm{a}}$

$66.58^{\mathrm{a}}$

$\begin{array}{lll}62.50^{\mathrm{b}} & 0.61 & 0.035\end{array}$

overall

$36-52$

$63.22^{\mathrm{ab}} 65.30^{\mathrm{a}}$

$\begin{array}{llll}66.00^{\mathrm{a}} & 62.02^{\mathrm{b}} & 0.58 & 0.045\end{array}$

Egg number

week 36-40

$40-44$

$19.86^{\mathrm{b}} \quad 24.25^{\mathrm{a}}$

$\begin{array}{llll}22.05^{\mathrm{ab}} & 22.33^{\mathrm{ab}} & 0.62 & 0.038\end{array}$

$\begin{array}{llllll}22.83 & 26.30 & 24.33 & 22.75 & 0.80 & 0.380\end{array}$

$44-48$

$21.77 \quad 23.54$

23.65

$\begin{array}{llll}22.99 & 0.56 & 0.659\end{array}$

48-52

$22.30 \quad 24.92$

23.99

$\begin{array}{llll}22.87 & 0.66 & 0.542\end{array}$

overall

36-52

$21.69 \quad 24.75$

23.51

$22.73 \quad 0.62 \quad 0.380$

Egg mass, $g$

week 36-40

40-44

$1210^{\mathrm{b}} \quad 1564^{\mathrm{a}}$

$1439^{\mathrm{ab}} 1705^{\mathrm{a}}$

$1459^{a}$

$1394^{\mathrm{ab}}$

$\begin{array}{ll}42.53 & 0.015\end{array}$

44-48

$1401 \quad 1557$

$1587^{\mathrm{ab}}$

$1390^{\mathrm{b}}$

$52.08 \quad 0.021$

48-52

$1420^{\mathrm{b}} 163$

$1575 \quad 1435$

$\begin{array}{ll}37.95 & 0.281\end{array}$

overall 36-52

$1368^{\mathrm{b}} \quad 1614^{\mathrm{a}} \quad 1550^{\mathrm{ab}} \quad 1408^{\mathrm{ab}} \quad 40.94 \quad 0.039$

${ }^{a b}$ means with different superscipts within a row are significantly different at $P<0.05 ;{ }^{1}$ SEM - standard error of means; ${ }^{2} P$ - overall treatment

in comparison with the control group and the diet containing $9 \mathrm{~g} \cdot \mathrm{kg}^{-1}$ of thyme. The improvement in egg weight with 3 or $6 \mathrm{~g} \cdot \mathrm{kg}^{-1}$ of thyme supplementation may be due to the supply of certain compounds that improve digestion and absorption of nutrients in the digestive tract. Moreover, it could be also attributed to the biological activity of compounds such as thymol that are found in thyme a cause greater feed efficiency and utilization, resulting in improved productive performance. The results from thyme supplementation are in agreement with Bölükbaşi et al. (2008), who reported that supplementing 200 $\mathrm{mg}$ thyme oil per $\mathrm{kg}$ diet significantly improved the egg weight of laying hens by $9.78 \%$ compared with a control diet. Mansoub (2011) found that thyme supplementation to a layer diet improved egg weight throughout the period from 60 to 70 weeks of age.

In the present study, egg number was not statistically influenced by the dietary thyme, except in the period from 36 to 40 weeks of age. The largest number of eggs was produced by birds fed the diet supplemented with $3 \mathrm{~g} \cdot \mathrm{kg}^{-1}$ of thyme. In contrast, the smallest number of eggs was recorded for the control group through 36 to 40 weeks of age.

Egg mass was significantly affected by thyme supplements at different ages as compared with the period from 44 to 48 weeks of age $(P<0.05)$. Birds fed $3 \mathrm{~g} \cdot \mathrm{kg}^{-1}$ of thyme had greater $(P<0.05)$ egg mass values than those fed the other diets. Radwan et al. (2008) pointed out that dietary supplementation of thyme $\left(10 \mathrm{~g} \cdot \mathrm{kg}^{-1}\right.$ diet $)$ to the basal diet exhibited a significantly positive effect on the egg production rate, egg mass and feed conversion ratio. Significant effects on egg weight and egg mass could be due the positive effect of the thyme herb on reduction of the number of pathogenic microbes in the digestive tract, improvement in immunity and performance of the birds (Shahryar et al., 2011). Lee et al. (2003) concluded that the presence of harmful bacteria in the digestive tract increases the lysis and deamination of protein and amino acids of nutrients, maybe due to secretory substances from these bacteria such as urease.

The effect of thyme supplementation on egg quality parameters of Hi-sex hens is given in Table 3. Overall, egg quality criteria were significantly $(P<0.05)$ influenced by dietary treatments. The highest values of the egg shape index, yolk index and Haugh unit score were achieved by birds fed the diet with $6 \mathrm{~g} \cdot \mathrm{kg}^{-1}$ of thyme compared with the other diets. Conversely, the highest values of yolk and shell percentage, as well as shell thickness and yolk-to-albumin ratio were achieved by birds fed the diet with $9 \mathrm{~g} \cdot \mathrm{kg}^{-1}$ of thyme compared with the other levels of thyme addition. A study by Mansoub (2011) revealed that egg quality parameters were significantly $(P<0.05)$ affected by thyme supplementation to layer diets, the highest yolk index value was seen in the $2 \%$ thyme group. In contrast, Mohebbifar and Torki (2010) showed that thyme added to a basal diet had no significant effect on egg quality criteria among treatments. Haugh unit score, the key indicator of interior egg quality, was not influenced by diets supplemented with thyme powder (Radwan et al., 2008). 
Table 3. Effects of dietary thyme supplement on egg quality criteria of laying hens from 36 to 52 weeks of age

\begin{tabular}{|c|c|c|c|c|c|c|}
\hline \multirow{2}{*}{$\begin{array}{l}\text { Egg quality } \\
\text { criteria }\end{array}$} & \multirow{2}{*}{ Control } & \multicolumn{3}{|c|}{ Thyme, $\mathrm{g} \cdot \mathrm{kg}^{-1}$ of control diet } & \multirow{2}{*}{$\mathrm{SEM}^{1}$} & \multirow{2}{*}{$P^{2}$} \\
\hline & & 3 & 6 & 9 & & \\
\hline Albumin, $\%$ & $66.48^{\mathrm{a}}$ & $62.37^{\mathrm{bc}}$ & $65.13^{\mathrm{ab}}$ & $60.06^{c}$ & 0.84 & 0.013 \\
\hline Yolk, \% & $24.36^{b}$ & $27.76^{a}$ & $26.35^{\mathrm{ab}}$ & $28.54^{a}$ & 0.56 & 0.045 \\
\hline Shell, \% & $11.84^{b}$ & $12.54^{b}$ & $11.19^{b}$ & $14.08^{\mathrm{a}}$ & 0.33 & 0.003 \\
\hline Egg shape index & $\times 79.30^{b}$ & $78.97^{\mathrm{bc}}$ & $82.75^{\mathrm{a}}$ & $76.71^{\mathrm{c}}$ & 0.65 & 0.001 \\
\hline Shell thickness & $0.35^{c}$ & $0.40^{\mathrm{ab}}$ & $0.38^{\mathrm{bc}}$ & $0.42^{\mathrm{a}}$ & $<0.01$ & 0.003 \\
\hline Yolk index & $38.67^{\mathrm{ab}}$ & $37.70^{\mathrm{b}}$ & $41.64^{a}$ & $40.62^{a b}$ & 0.64 & 0.035 \\
\hline $\begin{array}{l}\text { Yolk: albumin } \\
\text { ratio }\end{array}$ & $0.38^{b}$ & $0.46^{\mathrm{b}}$ & $0.42^{\mathrm{ab}}$ & $0.49^{\mathrm{a}}$ & 0.01 & 0.030 \\
\hline Haugh unit & $84.30^{\mathrm{b}}$ & $83.08^{b}$ & $90.30^{\mathrm{a}}$ & $78.07^{\circ}$ & 83.94 & $<0.001$ \\
\hline
\end{tabular}

\section{Blood metabolites}

Biochemical blood parameters are usually related to health status. These parameters are vital indicators of the nutritional and physiological status of birds and animals. The effects of thyme supplementation on blood metabolites of Hi-Sex laying hens are shown in Table 4. Blood protein, albumin, urea, total cholesterol, IgG and IgA were significantly $(P<0.05)$ influenced by thyme supplementation, while HDL-cholesterol and IgM were not affected. Dietary supplementation of thyme exhibited a significantly positive impact on parameters related to immunity and lipid profile, which is in accordance with the findings of Hashemipour et al. (2013).

In the current study, addition of $6 \mathrm{~g} \cdot \mathrm{kg}^{-1}$ of thyme powder reduced serum triglyceride and LDL-cholesterol concentrations compared with the other groups. The total cholesterol level was significantly $(P<0.001)$ lowered by the diet with $3 \mathrm{~g} \cdot \mathrm{kg}^{-1}$

Table 4. Effects of dietary thyme supplement on blood profile of laying hens at 52 weeks of age

\begin{tabular}{|c|c|c|c|c|c|c|}
\hline \multirow{2}{*}{ Blood profile } & \multirow{2}{*}{ Control } & \multicolumn{3}{|c|}{ Thyme, $\mathrm{g} \cdot \mathrm{kg}^{-1}$ of control diet } & \multirow{2}{*}{ SEM $^{1}$} & \multirow{2}{*}{$P^{2}$} \\
\hline & & 3 & 6 & 9 & & \\
\hline Total protein, $\mathrm{g} \cdot \mathrm{dl}^{-1}$ & $4.47^{\mathrm{bc}}$ & $4.60^{b}$ & $4.25^{c}$ & $4.88^{\mathrm{a}}$ & 0.07 & 0.001 \\
\hline Albumin, $g \cdot \mathrm{dl}^{-1}$ & $2.45^{\mathrm{a}}$ & $2.49^{a}$ & $2.28^{b}$ & $2.44^{a}$ & 0.02 & 0.009 \\
\hline Urea, $g \cdot \mathrm{dl}^{-1}$ & $2.47^{\mathrm{a}}$ & $2.09^{a b}$ & $1.17^{\mathrm{b}}$ & $1.91^{\circ}$ & 0.14 & 0.001 \\
\hline \multicolumn{7}{|l|}{ Lipid profile, $\mathrm{mg} \cdot \mathrm{dl}^{-1}$} \\
\hline triglycerides & $183^{\mathrm{a}}$ & $154^{\mathrm{ab}}$ & $134^{b}$ & $178^{\mathrm{a}}$ & 7.35 & 0.029 \\
\hline total cholesterol & $171^{\mathrm{a}}$ & $111^{c}$ & $150^{b}$ & $171^{\mathrm{a}}$ & 7.36 & $<0.001$ \\
\hline HDL-cholesterol & 93.28 & 61.13 & 83.50 & 88.68 & 5.50 & 0.161 \\
\hline LDL-cholesterol & $56.61^{\mathrm{a}}$ & $45.87^{\mathrm{ab}}$ & $37.29^{b}$ & $36.41^{b}$ & 2.87 & 0.011 \\
\hline \multicolumn{7}{|c|}{ Immunoglobulin, $\mathrm{mg} \cdot \mathrm{dl}^{-1}$} \\
\hline $\lg G$ & $1.27^{\mathrm{b}}$ & $2.31^{\mathrm{a}}$ & $2.30^{\mathrm{a}}$ & $1.31^{b}$ & 0.15 & $<0.001$ \\
\hline $\lg M$ & 12.54 & 14.75 & 13.57 & 15.71 & 0.55 & 0.343 \\
\hline $\lg A$ & $85.55^{b}$ & $105.68^{a}$ & $91.44^{b}$ & $85.00^{b}$ & 4.40 & 0.042 \\
\hline
\end{tabular}

${ }^{a b c}$ means with different superscipts within a row are significantly different at $P<0.05 ;{ }^{1}$ SEM - standard error of means; ${ }^{2} P$ - overall treatment of thyme. These results are partially in agreement with Mansoub (2011) who noted that thyme product supplementation to laying hen diets statistically decreased serum triglyceride and total cholesterol, as well as LDL and HDL cholesterol levels. In the same context, Rahimi et al. (2011) pointed out that blood triglyceride, total and LDL-cholesterol concentrations were significantly reduced by thyme added to chicken diets, but the HDL-cholesterol level was elevated by the same supplementation. The observed improvement in lipid profile may be because thymol enhances lipase and bile production, thus improving lipid digestion (Hernandez et al., 2004). Thymol, which is found in thyme, has been said to influence gastrointestinal tract activity, stimulating the secretion of salivary amylase, bile salt and pancreatic enzymes such as trypsin, chymotrypsin and lipase (Platel and Srinivasan, 2004).

In the poultry industry, it is important to stimulate the immune system to reduce or prevent infectious diseases. Many factors like failure of vaccination and inhibition of antibiotics can induce immunodeficiency. The usage of immune enhancers is a key solution to improving immunity and reducing susceptibility to infectious diseases in poultry farms. PFA, which are rich in flavonoids, extend the biological activity of ascorbic acid, act as antioxidants and may enhance immune function (Acamovic and Brooker, 2005). These findings can explain the nutritional and biological effects of examined treatments on immune parameters (Table 4). Compared with the control diet, immunoglobulin $\mathrm{G}$ and $\mathrm{A}$ were statistically $(P<0.05)$ affected in hens fed diets supplemented with thyme. In particular, serum IgG and IgA were elevated in birds fed a diet supplemented with $3 \mathrm{~g} \cdot \mathrm{kg}^{-1}$ of thyme $(P<0.001$ and $P<0.042$, respectively), in contrast with the other dietary groups. These results are partially in agreement with Karimi (2014), who found that medicinal herbs supplemented to layer diets did not significantly affect IgM compared with the control group.

Adding thyme to layer diets may improve the immune system due to the increase in immunoglobulin concentrations ( $\operatorname{IgG}, \operatorname{Ig} A$ and $\operatorname{Ig} M)$ in layers given diets with thyme versus hens fed a control diet. It is likely that a lower dose of natural phytogenic feed additives maybe needed to stimulate the humoral immune response. Previous studies showed that thyme and its ingredients could activate immune functions such as lymphocyte proliferation, phagocytosis, and red and white blood cell counts and haemoglobin levels (Hashemipour et al., 2013). 


\section{Antioxidant indices}

The antioxidant properties of aromatic herbs may deserve special attention because undesirable oxidation causes unacceptable changes in flavour, colour, odour, and other quality factors of the egg shell (Bozkurt et al., 2014). The effect of dietary thyme on antioxidant parameters, including serum activity of SOD and the concentrations of GSH and MDA, of Hi-Sex laying hens is presented in Table 5. In general, serum SOD activity and GSH concentrations were significantly increased in the groups fed diets with added thyme ( $P=0.010$ and $P<0.001$, respectively). The MDA concentration was decreased $(P=0.048)$ by the addition of $9 \mathrm{~g} \cdot \mathrm{kg}^{-1}$ thyme in comparison with the other groups. The serum MDA concentration is an indicator for evaluating antioxidant systems. The same results were reported by Hashemipour et al. (2013), Ashour et al. (2014) and Alagawany et al. (2015b), who noted that the intake of herbs or their ingredients resulted in an increase in serum antioxidant enzyme activities such as SOD and GSH-Px and in a decrease in the MDA concentration. SOD is a metalloprotein enzyme that mainly contributes to the antioxidant defense system. Consequently, elevated levels of this enzyme may improve the steady state of the antioxidant system of poultry. Therefore, the biological effects of antioxidant activity would be expected to improve poultry health. From our findings, it can be stated that the use of thyme as a phytogenic feed additive could be applied in the future to improve the nutritional and economical aspects of poultry breeding. It is suggested that the high biological activity of thyme as a natural antioxidant is attributed to the presence of phenolic hydroxyl groups that serve as a hydrogen donor to the proxy radicals produced in the first stage of lipid oxidation, thus inhibiting the formation of hydroxyl peroxide (Hashemipour et al., 2013). Botsoglou et al. (1997) demonstrated that use of $30 \mathrm{~g} \cdot \mathrm{kg}^{-1}$ of thyme delayed lipid oxidation of eggs stored in a refrigerator.

Table 5. Effects of dietary thyme supplement on superoxide dismutase (SOD) and reduced glutathione (GSH) activities and malondialdehyde (MDA) concentration in serum of laying hens at 52 week of age

\begin{tabular}{|c|c|c|c|c|c|c|}
\hline \multirow{2}{*}{$\begin{array}{l}\text { Oxidative } \\
\text { status }\end{array}$} & \multirow{2}{*}{ Control } & \multicolumn{3}{|c|}{ Thyme, $\mathrm{g} \cdot \mathrm{kg}^{-1}$ of control diet } & \multirow{2}{*}{\multicolumn{2}{|c|}{ SEM $^{1} P^{2}$}} \\
\hline & & 3 & 6 & 9 & & \\
\hline $\mathrm{SOD}, \mathrm{U} \cdot \mathrm{ml}^{-1}$ & $207^{\mathrm{b}}$ & $278^{a}$ & 212 & 277 & 1.8 & \\
\hline $\begin{array}{l}\mathrm{GSH}, \mathrm{ng} \cdot \mathrm{g}^{-1} \\
\text { tissue }\end{array}$ & $9.02^{c}$ & $12.30^{a}$ & $11.16^{b}$ & $11.98^{a}$ & $0.3^{3}$ & \\
\hline $\mathrm{MDA}, \mu \mathrm{mol} \cdot \mathrm{I}^{-1}$ & $4.47^{\mathrm{a}}$ & $4.12^{\mathrm{a}}$ & $4.16^{\mathrm{a}}$ & $3.74^{b}$ & 0.17 & 0.0 \\
\hline
\end{tabular}

${ }^{a b}$ means with different superscipts within a row are significantly different at $P<0.05$; ${ }^{1}$ SEM - standard error of means; ${ }^{2} P$ - overall treatment
It seems that thyme supplementation to layer diets was effective in enhancing the antioxidant ability of the birds, which appeared to lower mortality. Thyme is a rich source of beneficial phenolic compounds, thymol and related effective compounds having strong antioxidant activity (Yanishlieva et al., 1999). Herbal additives may have more than one mechanism, including affecting feed intake and conversion, stimulating the secretion of digestive enzymes and gastrointestinal motility, as well as immune and endocrine functions, besides antioxidant, antimicrobial, antiviral, anti-inflammatory, anthelminthic and coccidiostat activities (Basmacioğlu et al., 2010).

\section{Conclusions}

In view of the above findings and discussion, we conclude that thyme supplementation $(3,6$ and $9 \mathrm{~g} \cdot \mathrm{kg}^{-1}$ ) did not affect body weight change, feed consumption, or feed conversion ratio, but thyme supplementation with $3 \mathrm{~g} \cdot \mathrm{kg}^{-1}$ diet led to improvement in egg weight and egg mass, as well as in immune functions and antioxidant enzyme activities. In addition, layers fed the diet supplemented with 3 and $9 \mathrm{~g} \cdot \mathrm{kg}^{-1}$ of thyme had a lower lipid profile or lipid peroxidation rate in serum, respectively.

\section{References}

Abd El-Wareth A.A.A., Kehrausa S., Hippenstiela F., Südekum K.H., 2012. Effects of thyme and oregano on growth performance of broilers from 4 to 42 days of age and on microbial counts in crop, small intestine and caecum of 42-day-old broilers. Anim. Feed Sci. Tech. 178, 198-202

Acamovic T., Brooker J.D., 2005. Biochemistry of plant secondary metabolites and their effects in animals. Proc. Nutr. Soc. 64, 403-412

Akiba Y., Jensen L.S., Bart C.R., Kraeling R.R., 1982. Plasma estradiol, thyroid hormones and liver lipids determination in birds. J. Nutr. 112, 299-308

Alagawany M.M., Farag M.R., Dhama K., Abd El-Hack M.E., Tiwari R., Alam G.M., 2015a. Mechanisms and beneficial applications of resveratrol as feed additive in animal and poultry nutrition: A review. Int. J. Pharmacol. 11, 213-221

Alagawany M.M., Farag M.R., Dhama K., 2015b. Nutritional and biological effects of turmeric (Curcuma longa) supplementation on performance, serum biochemical parameters and oxidative status of broiler chicks exposed to endosulfan in the diets. Asian J. Anim. Vet. Adv. 10, 86-96

Alcicek A., Bozkurt M., Cbuk M., 2003. The effect of an essential oil combination derived from selected herbs growing wild in Turkey on broiler performance. S. Afr. J. Anim. Sci. 33, 89-94

Amad A.A., Manner K., Wendler K.R., Neumann K., Zentek J., 2011. Effects of a phytogenic feed additive on growth performance and ileal nutrient digestibility in broiler chickens. Poultry Sci. 90, 2811-2816

Ashour E.A., Alagawany M., Reda F.M., Abd El-Hack M.E., 2014. Effect of supplementation of Yucca schidigera to growing rabbits diets on growth performance, carcass characteristics, serum biochemistry and liver oxidative status. Asian J. Anim. Vet. Adv. 9, 732-742 
Awosanya B., Joseph J.K., Olaosebikan O.D., 1998. Effect of age of birds on shell quality and component yield of egg. Nigerian $\mathrm{J}$. Anim. Prod. 25, 68-70

Basmacioğlu M.H., Baysal S., Misirlioglu Z., Polat M., Yilmaz H., Turan N., 2010. Effects of oregano essential oil with or without feed enzymes on growth performance, digestive enzyme, nutrient digestibility, lipid metabolism and immune response of broilers fed on wheat-soybean meal diets. Brit. Poultry Sci. 51, 67-80

Beutler E., Duron O., Kelly B.M., 1963. Improved method for the determination of blood glutathione. J. Lab. Clin. Med. 61, 882-890

Botsoglou N.A., Yannakopoulos A.L., Fletouris D.J., Tserveni-Goussi A.S., Fortomaris P.D., 1997. Effect of dietary thyme on the oxidative stability of egg yolk. J. Agr. Food Chem. 45, 3711-3716

Bozkurt M., Hippenstiel F., Abdel-Wareth A.A.A., Kehraus S., Küçükyilmaz K., Südekum K.-H., 2014. Effects of selected herbs and essential oils on performance, egg quality and some metabolic activities in laying hens - a review. Eur. Poultry Sci. 78, $1-15$

Bölükbaşi Ş.C., Erhan M.K., Kaynar Ö., 2008. The effect of feeding thyme, sage and rosemary on laying hen performance, cholesterol and some proteins ratio of egg yolk and Escherichia Coli count in feces. Arch. Geflügelk. 72, 231-237

Card L.E., Nesheim M.C., 1972. Poultry Production. $11^{\text {th }}$ Edition. Lea and Febiger, Philadelphia, PA (USA)

Dhama K., Chakraborty S., Tiwari R., Verma A.K., Saminathan M., Amarpal Malik Y.S., Nikousefat Z., Javdani M., Khan R.U., 2014. A concept paper on novel technologies boosting production and safeguarding health of humans and animals. Res. Opin. Anim. Vet. Sci. 4, 353-370

Dhama K., Latheef S.K., Mani S. et al., 2015. Multiple beneficial applications and modes of action of herbs in poultry health and production - A review. Int. J. Pharmacol. 11, 152-176

Funk E.M., Froning G., Grottes G., Forward R., Kinder J., 1958. Quality of eggs laid by caged layers. World Poultry Sci. J. 15, 207

Hashemipour H., Kermanshahi H., Golian A., Veldkamp T., 2013. Effect of thymol and carvacrol feed supplementation on performance, antioxidant enzyme activities, fatty acid composition, digestive enzyme activities, and immune response in broiler chickens. Poultry Sci. 92, 2059-2069

Hernandez F., Madrid J., Garcia V., Orengo J., Megias M.D., 2004. Influence of two plant extracts on broilers performance, digestibility, and digestive organ size. Poultry Sci. 83, 169-174

Hong J.C., Steiner T., Aufy A., Lien T.F., 2012. Effects of supplemental essential oil on growth performance, lipid metabolites and immunity, intestinal characteristics, microbiota and carcass traits in broilers. Livest. Sci. 144, 253-262

Jensen C., Engberg R., Jakobsen K., Skibsted L.H., Bertelsen G., 1997. Influence of the oxidative quality of dietary oil on broiler meat storage stability. Meat Sci. 47, 211-222
Karimi A., 2014. The impact of adding the mixture of medicinal herbs to the diet on the qualitative characteristics of egg. Int. J. Anim. Vet. Adv. 6, 34-39

Khan R.U., Naz S., Nikousefat Z., Tufarelli V., Laudadio V., 2012. Thymus vulgaris: alternative to antibiotics in poultry feed. World Poultry Sci. J. 68, 401-408

Lee K.W., Everts H., Kappert H.J., Frehner M., Losa R., Beynen A.C., 2003. Effects of dietary essential oil components on growth performance, digestive enzymes and lipid metabolism in female broiler chickens. Brit. Poultry Sci. 44, 450-457

Mansoub N.H., 2011. Assessment on effect of thyme on egg quality and blood parameters of laying hens. Ann. Biol. Res. 2, 417-422

Mohebbifar A., Torki M., 2010. Effects of adding mixed powder of garlic and thyme to diets included graded levels of rice bran on productive performance of laying hens and egg quality characteristics. Adv. Environ. Biol. 4, 469-476

NRC, 1994. Nutrient Requirements of Poultry. $9^{\text {th }}$ revised Edition. National Academic Press. Washington, DC

Platel K., Srinivasan K., 2004. Digestive stimulant action of spices: A myth or reality? Indian J. Med. Res. 119,167-179

Radwan N.L., Hassan R.A., Qota E.M., Fayek H.M., 2008. Effect of natural antioxidant on oxidative stability of eggs and productive and reproductive performance of laying hens. Int. J. Poultry Sci. 7, 134-150

Rahimi S., Teymouri Zadeh Z., Karimi Torshizi M.A., Omidbaigi R., Rokni H., 2011. Effect of the three herbal extracts on growth performance, immune system, blood factors and intestinal selected bacterial population in broiler chickens. J. Agr. Sci. Tech. 13, 527-539

Rice-Evans C.A., Miller N.J., Bolwell P.G., Bramley P.M., Pridham J.B., 1995. The relative antioxidant activities of plant-derived polyphenolic flavonoids. Free Radical Res. 22, 375-383

Shahryar H.A., Gholipoor V., Ebrahimnezhad Y., Monirifar H., 2011. Comparison of the effects of thyme and oregano on egg quality in laying Japanese quail. J. Basic Appl. Sci. Res. 1, 2063-2068

SPSS, 2008. Statistical Package for the Social Sciences, ver. 17.0. SPSS Inc., Chicago, IL, USA

Tiihonen K., Kettunen H., Bento M.H., Saarinen M., Lathinen S., Ouwehand A.C., Schulze H., Rautonen N., 2010. The effect of feeding essential oils on broiler performance and gut microbiota. Brit. Poultry Sci. 51, 381-392

Winterbourn C.C., Hawkins R.E., Brain M., Carrell R., 1975. The estimation of red cell superoxide dismutase activity. J. Lab. Clin. Med. 85, 337-341

Yanishlieva N.V., Marinova E.M., Gordon M.H., Raneva V.G., 1999. Antioxidant activity and mechanism of action of thymol and carvacrol in two lipid systems. Food Chem. 64, 59-66 